\title{
A Comparative Study of Performance Between Operators With Work Discontinuity and Without Work Discontinuity
}

\author{
Josefa Angelie D. Revilla \\ University of the Philippines Los Baňos, Laguna, Philippines \\ Iris Ann G. Martinez \\ University of the Philippines Diliman, Quezon City, Philippines
}

\begin{abstract}
In situations where discontinuity in operation occurs, specifically in a country where coontractualization has an increasing trend, the performance level of operators after the work break is of great interest. Existing studies have found that the performance of an operator declines after her operation is completely stopped. However, when the operator performed other tasks (may it be similar or not from her previous task) during the work break, the performance after the work break seems to be affected at different level. Contractual and regular operators from a semiconductor and textile company were considered to replicate a discontinuous and continuous operation. The processing times of contractual workers before and after several months of work break were compared. Two types of work break were seen to have significant effect on an operator's performance after the work break, Type 1: 0\% to $40 \%$ similarity from previous task and Type $2: 40 \%$ to $97 \%$ similarity from previous task. One can find that when $21 \%$ of tasks performed during the work break are similar to the operator's previous task, there would be no change in her performance upon returning. On the other hand, a 5\% decline in performance was observed after work break type 1 and an $8.54 \%$ improvement after work break type 2 . Also, a remission rate of $18 \%$ from end of stint 1 to start of stint 2 under work break type 1 was seen, while $8 \%$ for work break type 2 . This may also be true to other industries. Thus, further study is suggested.
\end{abstract}

Keywords: performance of contractual operators, effects of work break, remission rate

\section{Occurrence of Work Break}

Work interruption has been a part of almost all operations in many manufacturing industries. It is unavoidable. A work break may be defined as the disruption of performing a specific operation. During the work break, an operator may do other operations (similar or different form her previous operation) or may have complete rest from doing any operation. Work breaks are caused by different scenarios, most of which are due to the very tight global market competition.

One of these is contractualization. This has been an employer strategy for the past decades to attain a

Josefa Angelie D. Revilla, assistant professor, Department of Industrial Engineering, University of the Philippines Los Ban̆os, Laguna, Philippines.

Iris Ann G. Martinez, Ph.D., associate professor, Department of Industrial Engineering and Operations Research, University of the Philippines, Diliman, Quezon City, Philippines.

Correspondence concerning this article should be addressed to Josefa Angelie D. Revilla, Department of Industrial Engineering, University of the Philippines Los Baňos, Laguna, Philippines, 4031. E-mail: jdrevilla@up.edu.ph. 
flexible work force and to limit labor costs (Ecumenical Institute for Labor Education and Research, 2000). Operators were allowed to work for a span of at most five months, before being terminated. This keeps the operators to become regular employees.

In the Philippines, $70 \%$ to $85 \%$ of the work force is now being outsourced (International Labor Rights Forum, 2008). This is a large number, making the effect of work break on operators an interesting and relevant concern. It is most likely that these contractual operators would be rehired a few months after their contract ends. Thus, the level of change in their performance after the work break is essential for their employers.

Another situation, where a work break occurs, is when an operator is transferred from one production process to another. This may be due to low demand forecast, machine breakdown, late raw material arrival, or other internal and external concerns.

Theoretically, one of the most common parameters used to measure the performance level of an operator is the learning curve. The concept behind learning curve states that when operations are done repeatedly, the time to finish them becomes shorter. However, according to Stump (2002), when an operation is interrupted, learning is lost. This simply states that if an operator is interrupted from work, her performance after the interruption tends to decline. This is where the concept of "forgetting" or "remission" applies.

\section{The Concept of Learning and Forgetting}

The concept of learning has been studied for a long time. As an operator learns or gains experience in a certain operation, her efficiency in performing the operation increases. It is revealed that high levels of previous experience are positively correlated with steady-state productivity levels (Shafer, Nembhard, \& Uzumeri, 2001). The concept of learning varies depending on the nature of production (Benkard, 2000).

Unlike the concept of learning, the concept of forgetting has been rarely studied. Forgetting rate is defined as the excess of actual time over learning-curve-predicted time (Bailey, 1989). The degree of forgetting is a function of the break length and the level of experience gained before the break (Globerson, Levin, \& Shtub, 1989). If learning increases through experience, forgetting increases as a function of a break from doing an operation. These two are found to have an exponential relationship, thus there is a tendency of a higher decline in performance level if a long work break is considered (Carlson \& Rowe, 1976).

Several other studies were conducted to determine the empirical relationship between learning and forgetting. In a dissertation by Kim (2008), entitled "Procedural Skills: From Learning to Forgetting", he examines the procedural skills of individuals who used key-based commands while others used mouse and menus. In his study, results show that retention intervals have clear effects on the amount of forgetting. Retention intervals of six, 12, and 18 days were considered. The study explains that as the retention interval increases, the amount of forgetting also increases.

The impact of the break length on forgetting is also important. A study conducted by Globerson et al. (1989) entitled "The Impact of Breaks on Forgetting in Performing a Repetitive Operation" considers a work break length of one to 82 days. It stated that performance deterioration due to breaks is just a few percentage points for a single day breaks and up to $70 \%$ for the longest break. Thus, as the work break length increases, performance deterioration also increases.

A hospital study relating to the relationship between learning and forgetting was also conducted by a previous research. It was found that the decreases in surgeon productivity are directly attributable to the length of work break between surgeries. Also, it shows little evidence that decreases in surgeon productivity are 
mitigated by the level of operation repetition prior to the break (Hockenberry, Lien, \& Chou, 2008).

Another study was conducted to determine the effects of work break on human capital. This study considered married women and what happens to their working performance after a long work break (Mincer \& Ofek, 1980). It stated that the wages at re-entry are on the average lower than the wages before work was interrupted, and the decline is bigger when the interruption is longer.

\section{Research Gap}

These studies highlighted the effects on the performance on stint 2 with respect to the length of work break (Figure 1). The work break length varies from either too long (such as more than a year) or too short (such as less than a week) Moreover, most of them, if not all, consider a work break with a complete stop in production. In some cases, a work break does not necessarily mean a complete stop in performing a certain operation. In some instances, other activities (related or unrelated to the previous operation) are performed during the work break. In these situations, the measure of the forgetting rate might be different.

\section{EXISTING RESEARCH STUDIES}

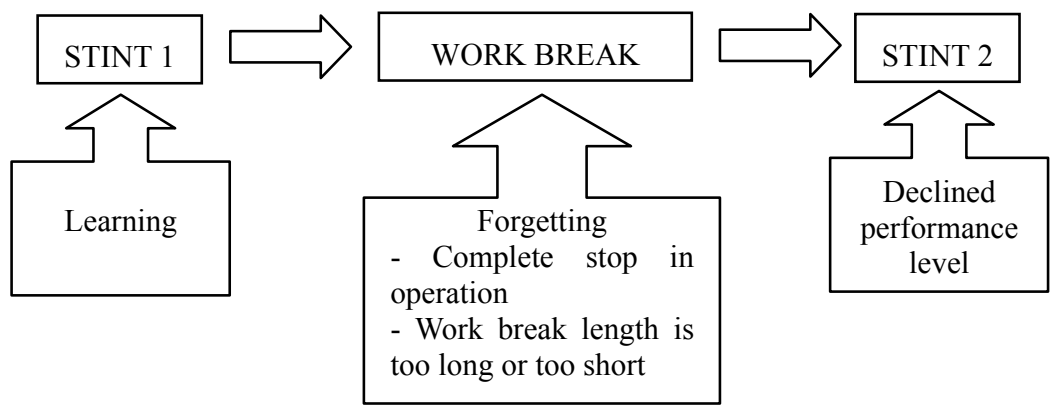

IN THIS STUDY

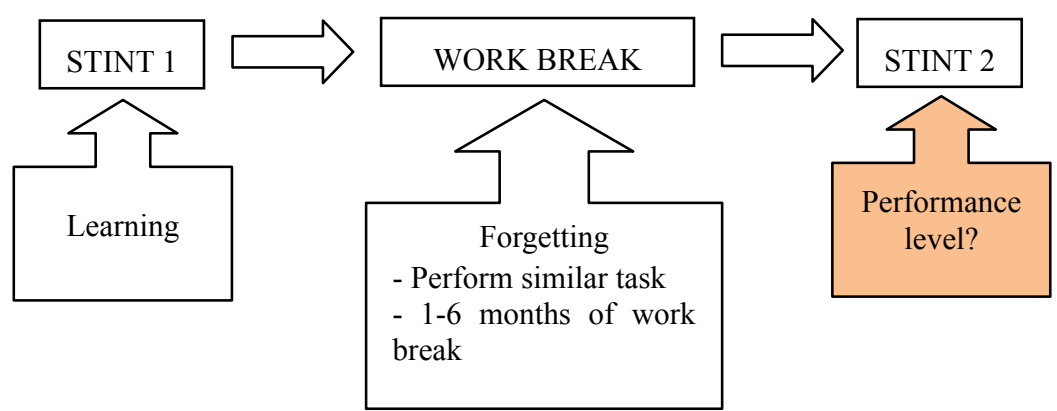

Figure 1. Summarized research gap of this study.

The study sought to analyze whether a work break from the same operation affects the average processing time of the operators. It specifically aimed:

- to determine the processing times of each operator before and after the work break;

- to determine whether the average processing time of operators varies significantly after a work break;

- to identify the factors that significantly affect the average processing time;

- to determine the positive or negative relationship between the average processing time and each of the four variables (work break length, number of unique operations during the work break, frequency of doing similar operation during the work break, and length of complete rest);

- to compare the performance of operators with work discontinuity and without work discontinuity. 


\section{Research Organization}

\section{Conceptual Framework}

Fig. 2 shows the conceptual framework of this research. This highlights the relationship of this study to studies about learning curve or learning rate and forgetting or remission rate.

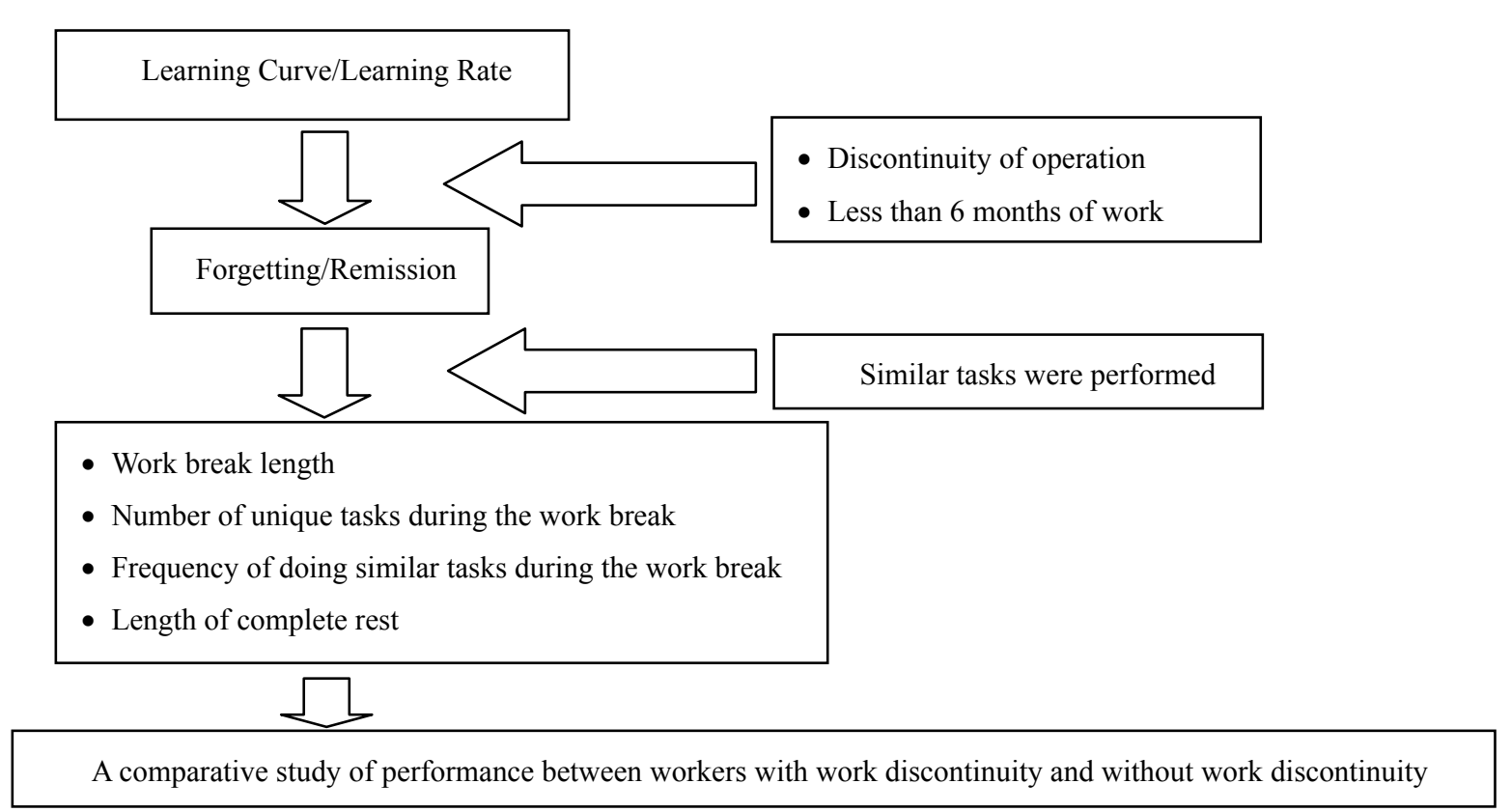

Figure 2. Flow diagram linking learning, forgetting, and the factors affecting forgetting.

Existing research studies show the relationship between the rate of learning and the rate of forgetting. Some of these studies have found that learning and forgetting go together. "Learning is a function of experience while forgetting is said to be a function of break length" (Thomassen, 2000).

In this study, other activities other than complete rest are taken to happen during the work break. The effects (i.e. correlation) of factors affecting the performance level of operators after a work break are investigated. These factors are the (1) work break length, (2) number of unique operations during the work break, (3) frequency of doing a similar operation during the work break, and (4) length of complete rest. These factors are considered because they were initially observed to have an effect on the average processing time after resumption of operation.

\section{Empirical Research}

Case studies from two companies have been investigated (Figure 3). Case study 1 involves a semiconductor company while case study 2 involves a textile company. Five specific cases that include different activities during the work break are found. These cases show different effects on the average processing time.

The four factors namely: (1) work break length, (2) number of unique operations, (3) frequency of performing similar operation, and (4) length of complete rest are considered because they initially show effects on the average processing time in case study 1 . In case study 1 , the study was able to take a small sample size. Furthermore, the work break length is short. To provide sufficient data and analyses of longer work break length, this study continues to case study 2 where a larger sample size is used and a more detailed work break analysis is considered. 


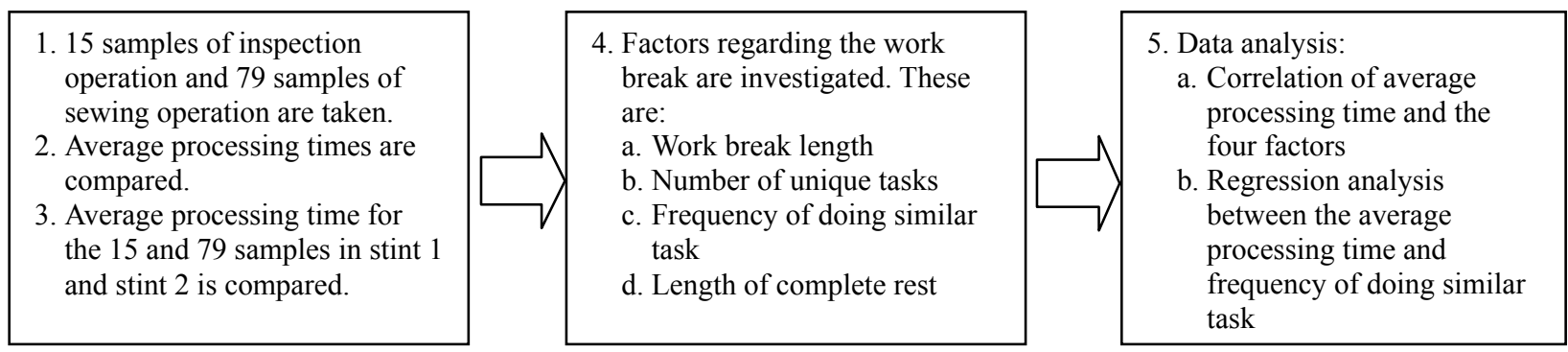

Figure 3. Specific methodology of the study.

\section{Definition of Factors Under Consideration}

Processing time. The processing time is the amount of time to perform a single operation for a single unit (or for a single piece of product). This is also called the observed time and is used to compute for the standard time of an operation.

Work break length. Work break length is the amount of time beginning after the end time of the operation on a product model until the start time of return to do exactly the same operation on exactly the same product. It is noted that the operator may do similar operation (i.e. same operation but on a different product model) during the work break.

The number of unique operations during the work break. The number of unique operations during the work break is the total number of different operations, including similar operation (i.e. same operation but different model), which the operator performed within her work break, for example, operator $A$ was doing operation 1 for product $X$ for three months. The demand for product $X$ is forecasted to decrease for the next month, thus several operators from product $X$ are transferred to other operations on other products. For the next two months, operator $A$ performs operation 1, operation 2, operation 3, operation 4, and operation 5 on different products. Then she is transferred back to her usual operation which is operation 1 for product $X$. The number of unique operations during the work break is the total number of operations that she performed (regardless of the product model) within the last two months. In this case, five operations are performed. This is counted to know if the exposure on many different operations affects the processing time of the operator when she resumes to her usual operation.

Frequency of doing similar operation during the work break. The frequency of doing similar operation during the work break is the number of operation (in percentage) similar to the operator's operation before the work break. In the example above, the frequency of doing similar operation during the work break would be the total frequency of performing operation 1 (regardless of the product model) over the total frequency of performing all the unique operations. This is computed to know if the degree of exposure to similar operations affects the processing time of the operator when she resumes her usual operation.

Length of complete rest. The length of complete rest is the total duration wherein the operator completely stops doing any operation. This is considered to confirm if no exposure to any operations affects the processing time of the operator when she resumes to her usual operation.

\section{Profile of the two companies}

The first company is a semiconductor company making computer parts. It involves machining and 
inspection operations. The other company is a manufacturer of baseball gloves, hockey gloves, and knee pads. The company involves many processes which are different sewing operations. Table 1 presents the summarized information of the two companies.

Table 1

Background of the Two Companies Considered in the Study

\begin{tabular}{|c|c|c|c|c|}
\hline Case & Product & General process & Kind of work & Use of contractual operators \\
\hline 1 & Actuator & $\begin{array}{l}\text { Machining, Washing, Inspection 1, Plating, } \\
\text { Inspection 2, and Packing }\end{array}$ & $\begin{array}{l}\text { Inspection process: } \\
10 \% \text { machine-paced and } 90 \% \\
\text { worker-paced }\end{array}$ & $\begin{array}{l}70 \% \text { are contractual operators } \\
\text { 1. Stint } 1=15-16 \text { days } \\
\text { 2. Work break }=10 \text { days } \\
\text { 3. Stint } 2=16-17 \text { days }\end{array}$ \\
\hline 2 & $\begin{array}{l}\text { Baseball } \\
\text { gloves }\end{array}$ & $\begin{array}{l}\text { Cutting, Stamping, Skiving, Matching } \\
\text { color, Inspection 1, Sewing (accessories), } \\
\text { Hot hand, Linings, Sewing (fingers), } \\
\text { Lacing, Inspection 2, Packing }\end{array}$ & $\begin{array}{l}\text { Sewing process: } \\
20 \% \text { machine-paced and } 80 \% \\
\text { worker-paced }\end{array}$ & $\begin{array}{l}80 \% \text { are contractual operators } \\
1 . \text { Stint } 1=2-3 \text { months } \\
\text { 2. Work break }=3 \text { months } \\
\text { 3. Stint } 2=2-3 \text { months }\end{array}$ \\
\hline
\end{tabular}

\section{Cases of Work Breaks}

For case study 2, five types of work breaks are initially established based on the commonality of the data. These five types of work breaks are then investigated for significance to the decline, improvement, or no change of the average processing time of the second stint. Table 2 discusses the five types of work breaks.

The study uses verified secondary data on the processing time, work break length, number of unique operations during the work break, frequency of doing similar operation during the work break, and length of complete rest. These data are taken from the company's daily production output records. The data are verified through actually observing sewing processes and taking the processing time of several samples.

Table 2

Initial Work Break Type That Was Observed

\begin{tabular}{cl}
\hline Type & Description \\
Type 1 & $\begin{array}{l}\text { Operator performed several other operations on different models, not including the operation that she did before the } \\
\text { work break. }\end{array}$ \\
Type 2 & $\begin{array}{l}\text { Operator performed several other operations on different models, including the operation that she performed before } \\
\text { the work break (only applying it on a different model). } 1 \% \text { to } 40 \% \text { of the operations are the same as her previous } \\
\text { operation. }\end{array}$ \\
Type 3 & $\begin{array}{l}\text { Operator performed several other operations on different models, including the operation that she performed before } \\
\text { the work break (only applying it on a different model). } 40 \% \text { to } 97 \% \text { of the operations are the same as her previous } \\
\text { operation. }\end{array}$ \\
Type 4 & $\begin{array}{l}\text { Operator performed several other operations on different models, not including the operation that she performed } \\
\text { before the work break, for a few months. Then, she did not do any operation related to the company for another few } \\
\text { months. }\end{array}$ \\
Type 5 & $\begin{array}{l}\text { Operator performed several other operations on different models, including the operation that she did before the work } \\
\text { break, for a few months. Then, she did not do any operation related to the company for another few months. }\end{array}$ \\
\hline
\end{tabular}

\section{Results and Discussion}

\section{Cases of Work Breaks With Significant Effects on the Average Processing Times of the Second Stint}

After analyzing and finding that work break types 1,2, 4, and 5 have no significant difference from one another, the four types of work break are regrouped and thus turned out to be work break type 1, while work break type 3 became work break type 2. Table 3 shows and discusses the regrouped work break cases. 
Table 3

Cases of Work Break With Significant Effect on the Average Processing Time on Stint 2

\begin{tabular}{lll}
\hline Work break type & Description & $\begin{array}{l}\text { Average processing time after } \\
\text { the work break }\end{array}$ \\
\hline 1 & $\begin{array}{l}\text { Operator performed several other processes on different models, } 1 \% \text { to } 40 \% 5.00 \% \text { increase in processing } \\
\text { of which are similar to the process that she did before the work break. }\end{array}$ \\
$\begin{array}{l}\text { Operator performed several other processes on different models, an average } 8.54 \% \text { decrease in processing } \\
\text { of } 40 \% \text { to } 97 \% \text { are similar to the process that she did before the work break. time }\end{array}$ \\
\hline
\end{tabular}

Equality of the Average Processing Time Before and After a Work Break

The average processing time before and after the work break is tested to see if they are significantly different from one another. The result shows that at a $99 \%$ confidence level, the average processing time after a work break type 1 is higher than the average processing time before the work break. It also shows that the average processing time after a work break type 2 is lower than the average processing time before the work break. Generally, the average processing time after is significantly different from the average processing time before the break.

\section{Correlation of the Average Processing Time and the Four Factors Hypothesized to Affect the Average Processing Time}

The study also analyzes the different variables affecting the average processing time after the work break. Four factors are considered. These are: (1) the length of the work break, (2) the number of unique operations during the work break, (3) the frequency of doing similar operation during the work break, and (4) the length of complete rest. These four factors are individually correlated with the average processing time. The correlation coefficient $(r)$ is computed and the result is shown in Table 4.

Table 4

Summary of Correlation Result Between the Average Processing Time on Stint 2 and the Four Factors

\begin{tabular}{|c|c|c|c|c|}
\hline & Work break length & $\begin{array}{l}\text { Number of unique operations } \\
\text { during the work break }\end{array}$ & $\begin{array}{l}\text { Frequency of doing similar } \\
\text { operation during the work break }\end{array}$ & $\begin{array}{l}\text { Length of complete } \\
\text { rest }\end{array}$ \\
\hline $\begin{array}{l}\text { Average } \\
\text { processing time } \\
\text { on stint } 2\end{array}$ & $\begin{array}{l}-0.0147 \\
\text { very weakly correlated } \\
0.8968 \\
\text { not significant }\end{array}$ & $\begin{array}{l}0.1514 \\
\text { very weakly correlated } \\
0.1799 \\
\text { not significant }\end{array}$ & $\begin{array}{l}-0.4954 \\
\text { moderately correlated } \\
0.0000 \\
\text { Significant }\end{array}$ & $\begin{array}{l}0.0793 \\
\text { very weakly correlated } \\
0.4842 \\
\text { not significant }\end{array}$ \\
\hline
\end{tabular}

The summary of correlation results shows that among the four variables, only the frequency of doing similar operation during the work break has a significant effect on the average processing time after the work break. Thus, the regression analysis that follows in the next section focuses on the relation between the average processing time and frequency of doing similar operation during the work break.

\section{Further Analysis of the Relationship Between the Average Processing Time and the Frequency of Doing Similar Operation}

Before conducting the regression analysis, the data are first tested to see if they met the assumptions for conducting a regression analysis. Based on the linearity test, it was seen that the data are not linearly related. So a non-linear regression is assumed. Several non-linear models are considered (logarithmic model, quadratic model, and exponential model). Based on the generated $R^{2}$ value among these three models, the best fit is the exponential (or decay) model. Thus, an exponential relationship is used. The generated exponential model is used to examine the specific relationship between the average processing time on stint 2 
and the frequency of doing similar operation during the work break. Equation (1) presents the generated regression model.

Equation (1): exponential regression model between the frequency of doing similar operation and the average processing time on stint 2

where:

$$
Y=b_{0}+\left(b_{1} \times{b_{2}}^{x}\right)
$$

$Y=$ average processing time on stint 2

$X=$ frequency of doing similar operation during the work break

$b_{0}=-12.8124$

$b_{1}=17.4578$

$b_{2}=0.9857$

$$
\text { Average processing time }=-12.8124+\left(17.4578 \times 0.9857^{\text {frequency }}\right)
$$

This shows a negative relationship and this is consistent with the correlation result. The goodness-of-fit of the model is moderate $\left(R^{2}=0.5086\right)$. This is not the usually high $R^{2}$ value but this is considerable. It does not indicate that the model is not a reliable equation. It just suggests that there are still other significant variables that can be considered which affect the average processing time on stint 2.

The actual average processing time and the theoretical average processing time are graphed together in Fig. 4. From here, one can see that the actual data are increasing up to approximately $40 \%$ of similar operation. This exhibits the specific forgetting behavior of operators that are considered in this study.

To provide a more general relationship, the theoretical data are computed using equation (1). One can see that there would be no change in the average processing time when the frequency of doing similar operation is $21 \%$. Moreover, if all of the operations during the work break are similar to the operator's previous operation, the average processing time is decreased by approximately $8.70 \%$. In the case when no operation is similar from the previous operation, the average processing time is increased by $4.65 \%$. Fig. 4 also conveys that the average processing time increases when the frequency of doing similar operation is between $0 \%$ to $21 \%$, while it decreases after $21 \%$.

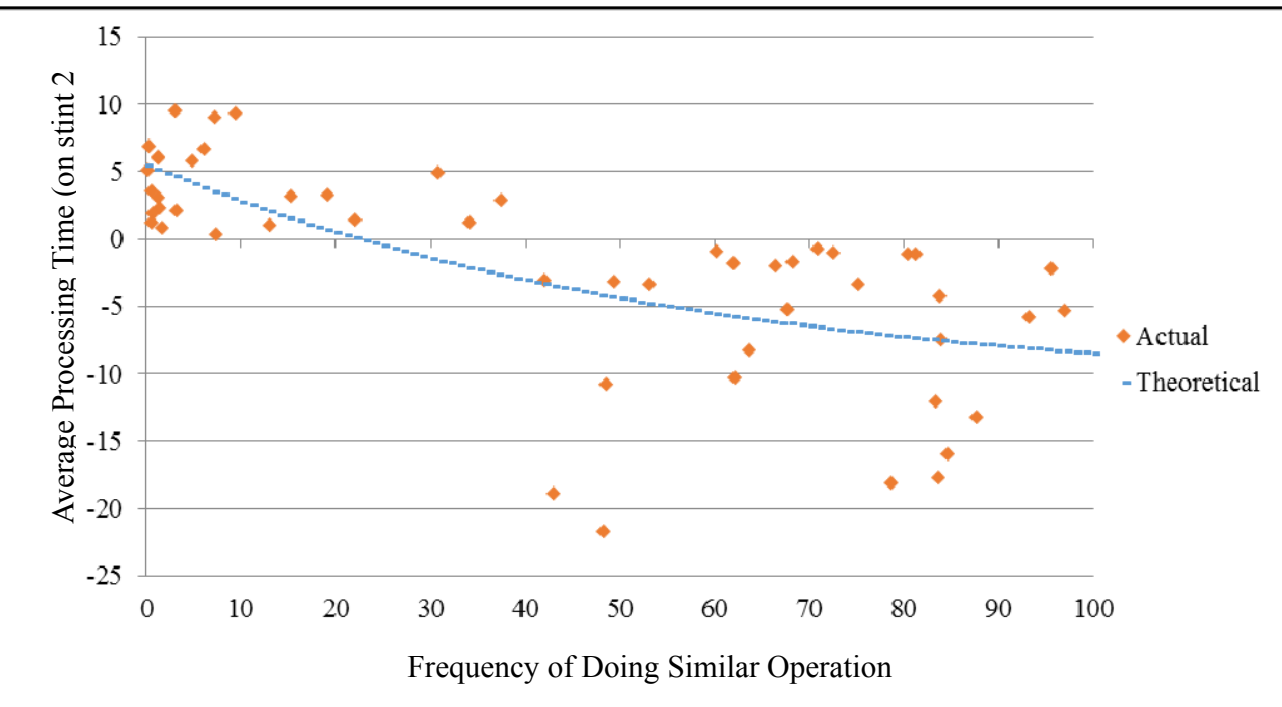

Figure 4. Exponential regression model between the frequency of doing similar operation and the average processing 
time on stint 2.

\section{Comparison Between the Average Processing Time of Operators Without Discontinuity and With Discontinuity}

Samples of a continuous operation are taken into account. The empirical behavior of the average processing time through time of a continuous operation, the average processing time through time after doing $0 \%$ to $40 \%$ similar operation during the work break, and the average processing time through time after doing $40 \%$ to $97 \%$ similar operation during the work break are graphed together in Fig. 5 to see their actual relationship with one another.

It shows that an average of $18 \%$ increase is expected from the last data point before the work break (point 1) to the first data point after work break type 1 ((point 3) (i.e. operator performs $0 \%$ to $40 \%$ of similar operation during the work break). On the other hand, an $8 \%$ increase is expected from the last data point before the work break (point 1) to the first data point after work break type 2 (point 2) (i.e. operator performs $40 \%$ to $97 \%$ of similar operation during the work break). These specific increases are computed by taking the average of the actual difference between last and first data points of the two stints.

Fig. 5 also illustrates that the average processing time before the work break (line 2) is lower than the average processing time after work break type 1 (line 3) while it is higher than the average processing time after work break type 2 (line 1).

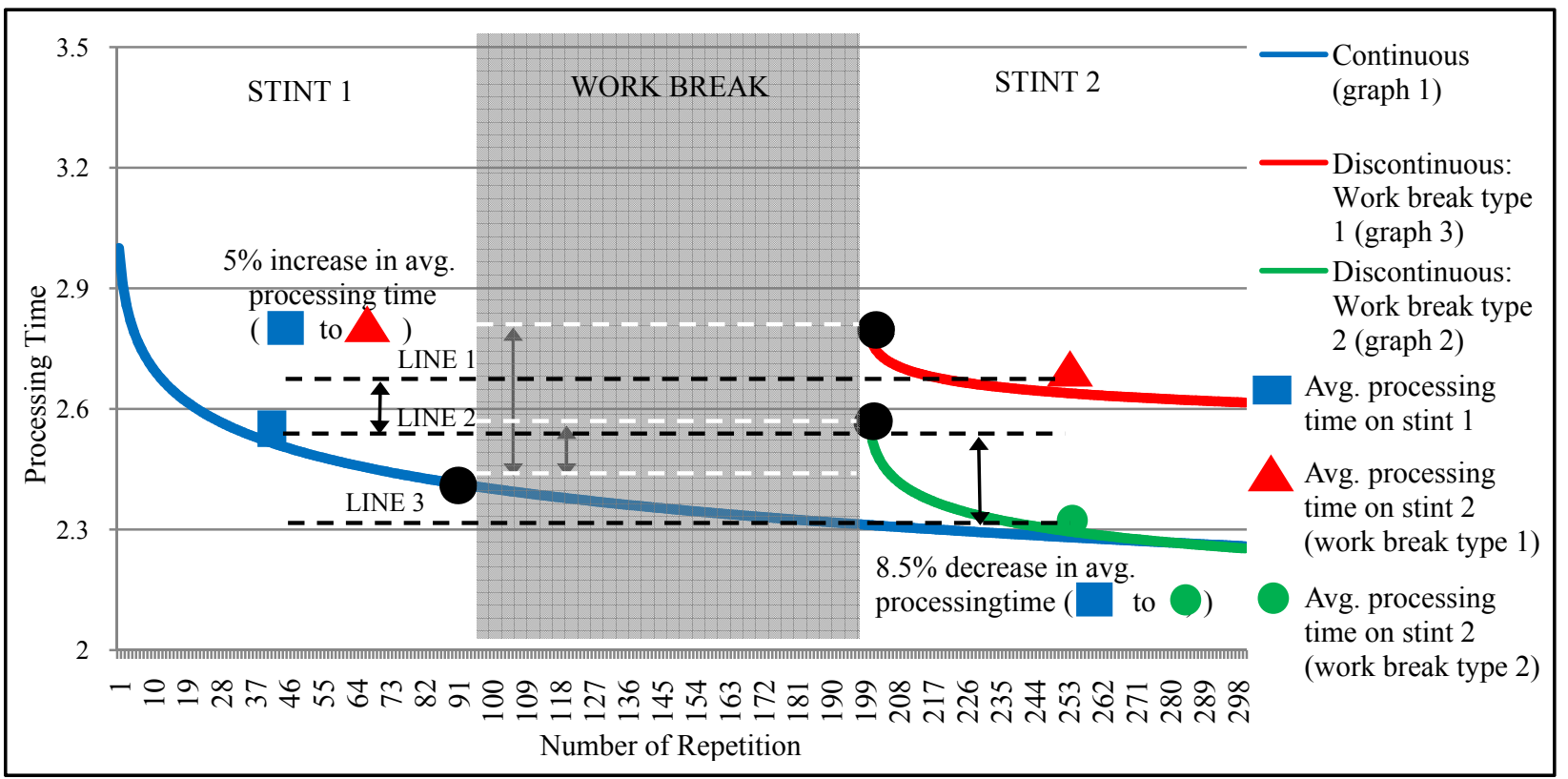

Figure 5. Summarized behavior of a continuous operation versus a discontinuous operation.

\section{Conclusions}

The result showed that there is a significant difference in the performance between workers with work discontinuity and without work discontinuity. For workers with work discontinuity, two cases have emerged to have significant effects on the average processing time on stint 2 compared to stint 1 : These are $0 \%$ to $40 \%$ of the operations performed during the work break similar to the previous operation and $40 \%$ to $97 \%$ of the operations performed during the work break similar to the previous operation. 
The operators with work break type 1 have a higher average processing time ( $5 \%$ increase) after the work break while operators with work break type 2 have a lower average processing time $(8.54 \%$ decrease $)$ after the work break.

On the other hand, of the four factors considered, frequency of doing similar operation has been found to be correlated with the average processing time on stint 2 . The regression analysis between the average processing time on stint 2 and the frequency of doing similar operation exhibits an exponential relationship.

Lastly, the result showed that an average of $18 \%$ increase in the processing time is expected from the first data point on stint 2 from the last data point on stint 1 when $0 \%$ to $40 \%$ of the operations during the work break are similar to the operation in stint 1 . While an $8 \%$ increase in the processing time is expected from the first data point on stint 2 from the last data point on stint 1 when $40 \%$ to $97 \%$ of the operations during the work break are similar to the operation in stint 1.

Generally, it can be said that the average processing time after a work break was influenced by the performance of similar operations during the work break. It can either cause the average processing time to increase or to decrease based on how frequent a similar operation was performed.

It is of importance to note that the study focuses more on the average instead of the point to point data because employers based the wage rate of operators on their average output per month. Thus, the increase in the average processing times before and after the work break is given more attention than the difference between last data point on stint 1 and the first data point on stint 2 . Moreover, the average represents the standard value of a data set so it is a much better parameter than point-to-point data.

\section{Area for Further Study}

While this research has seen some findings about the increase in average processing time on stint 2 , only two companies were considered. Thus, there is a need for further study to investigate the following:

- Percentage increase as a result of work break type 1 and work break type 2 must be studied in more depth to establish more accurate values. Values here were established as limited by the actual samples gathered.

- Other kinds of man and machine work must be investigated.

- Knowledge based work must be investigated.

- Taking other types of skill-based operations into consideration to see if same results would be found.

- Taking into consideration other factors that may affect the performance of operators after a work break.

\section{References}

Bailey, C. D. (1989). Forgetting and the learning curve: A laboratory study. Management Sci., 35(3), 340-352.

Benkard, C. L. (2000). Learning and forgetting: The dynamics of aircraft production. The American Economic Review, 90(4), 1036-1054.

Carlson, J. G., \& Rowe, A. J. (1976). How Much Does Forgetting Cost. Industrial Engineering, 8 (9), 40-47.

Ecumenical Institute for Labor Education and Research (EILER). (2000). Labor flexibilization and imperialist crisis: Intensifying exploitation, dismantling job security, liquidating unions. Philippines, Manila: Institute of Political Economy.

Globerson, S., Levin, N., \& Shtub, A. (1989). The impact of breaks on forgetting when performing a repetitive operation. IIE Trans., 21(4), 376-381.

Hockenberry, J., Lien, H. M., \& Chou, S. Y. (2008). The impacts of operation repetition and temporal breaks in production on human capital. Journal of Human Capital, 2(3), 303-335.

International Labor Rights Forum. (2008). Freedom at work: Contact labor and precarious labor. Retrieved from 
http://www.laborrights.org/end-violence-against-trade-unions/contract-labor-andprecarious-work

Kim, J. W. (2008). Procedural skills: From learning to forgetting. Retrieved from http://acs.ist.psu.edu/reports/kim08.pdf Mincer, J., \& Ofek, H. (1980). Interrupted work careers (NBER working paper 479). Cambridge, MA: National Bureau of Economic Research. Retrieved from http://www.nber.org/papers/w0479.pdf?new_window=1

Shafer, S. M., Nembhard, D. A., \& Uzumeri, M. V. (2001). The effects of operator learning, forgetting, and heterogeneity on assembly line productivity. Management Sci., 47(12), 1639-1653.

Stump, E. (2002). All About Learning Curves. Proceedings from SCEA Conference. Retrieved from http://www.galorath.com/images/uploads/LearningCurves1.pdf

Thomassen, A. (2000). Learning and forgetting curves: A practical study. Retrieved from http://www.orsnz.org.nz/conf33/papers/p63.pdf 